\title{
Problems of studying coral-reef ecosystems
}

\author{
B. V. Preobrazhensky \\ Laboratory of Tropical Seas, Institute of Marine Biology; Vladivostok, USSR
}

\begin{abstract}
The term "reef" has still to be defined in ecological terms. It is essential to discuss and to classify the most significant characteristics of coral-reef ecosystems. Coral reefs involve a number of interdependent problems of semantics, planetary and regional geotectonics, paleogeography, geomorphology, ecology, hydrobiology and zoogeography. From an ecological point of view, the solution to these problems requires analyzing the correlation between the notions "biocoenosis" and "ecosystem". We may regard a coral reef either as a "super organism" or as a complex aggregation of almost mutually independent organisms, more or less randomly composed during evolution. The pros and cons, as well as contradictions between these two possibilities can be largely settled by means of historical analyses.
\end{abstract}

\section{INTRODUCTION}

It is my aim to attempt formulating the main problems concerning the study of the coral reef as an ecosystem. Such endeavour is associated with a number of important general biological considerations: (1) the building of self-contained natural ecosystems and biocoenoses; (2) the realization of ecosystem regulation and its evolutionary stability; (3) the existence of life-forms and their dependence on environmental factors; (4) the understanding of the system's structural independence of reefs; (5) the development of a controlled model, prognoses regarding potential consequences of effects due to human activities; (6) the development of strategies and tactics of rational usage of natural ecosystems for man's purposes; (7) the construction of artificial ecosystems with high biological productivity.

\section{HISTORICAL ASPECTS}

Charles Darwin was the first to spark interest in the scientific study of coral reefs. Following Darwin, a traditional school emphasizing natural history and description tried to illucidate the origin of reefs. Such methods (e.g. Mergner, 1974) are determined by the desire to compare a great number of reef types, different forms of communities within a reef and reef areas, in order to establish some general regularities. Effects of biotic and abiotic factors upon communities and biocoenoses, influence of geomorphology, geological history and a dominant physiological factor 
upon the community structure were regarded by many authors as such regularities (e.g. Goreau, 1959; Stoddart, 1969; Dana, 1976; and others).

The establishment of typical sites of reefs is associated with the request to divide the reef structure both horizontally and vertically and to distinguish zones (Wells, 1954) and facies (Umgrove, 1940; Catala, 1950). The work on typifying reefs and their morphological features led to the publication of a periodical illustrated issue on reef terminology "Tethys". The reef can be studied as a geological body, as a plant-animal socium, as an ecosystem and so on.

\section{ASPECTS OF CLASSIFICATION AND TERMINOLOGY}

Basic aspects have been classified by Stoddart (1971) as substantive (what to study?), conceptual (how to explain?) and operational problems (how to study?). Among the conceptual problems we should consider the definition of a "reef". Originally, the term "reef" signified any shallow, rocky submerged obstacle to navigation. Thus far, the paradigm "reef" (a whole complex of descriptions) is quite differently interpreted by a navigator, geologist, ecologist, geomorphologist or economist; each one of these would come up with a different definition. It also remains obscure whether a reef can be regarded as a living unit, or superunit, or whether it can be interpreted as a geological body of certain genesis, a geomorphologic phenomen with a peculiar set of macro- and micro-relief forms; or, as a matter of fact, as a landscape phenomen characterized by a particular set of facies. Naturally, there are many requirements associated with the system to be termed "reef". We must elucidate the reasons for the reef formations, explain the unique stability of reefs, reveal their energy resources and their modes of energy accumulation. The practically closed, self-contained reef ecosystem exhibits an energetic balance which is presently believed to exceed that of the surrounding barren oceanic waters. The solution of these important problems constitutes an enormous challenge for human exploratory capabilities and is a basic prerequisite for continued utilization and preservation of this unique natural system.

I would like to discuss some possible approaches to the interpretation of a coral reef. We may assume, for instance, the reef to be an evolutive "superorganism" and certain groups of Linnean taxa to play the role of different "organs". Such a concept poses the question of how long and in what places such a reef can exist, as it is known that the existence of all biological taxa is limited in time and space. Considering a reef to be mortal in the sense of an organism, we must determine the period of its existence and the set of taxa necessary or sufficient to recognize the system as a reef. Such an analysis produces an impression of ephemerality and physical discontinuity of a reef. Consequently, the conclusion might be drawn that none of the ancient reef-like groupings can be called reefs. However, such conclusions contradict the well-known fact that reef bodies in the Pacific Ocean can exist over long geological periods and are, in fact, quite stable; this was evidenced by deep borings, for example, in the atolls Bikini, Funafuti, and Enivetok. We must conclude, therefore, that a reef exists most likely over long geological periods. When the ancient 
formations can be called reefs, the question arises how stability within a reef system can be maintained inspite of radical changes in its flora and fauna elements during evolution. It is practically impossible to find taxa (orders, families etc.) within a reef specific to this ecosystem. Can we then assume that a reef does not require a strict association with taxonomy and biological evolution?

If we regard a reef as an energetically closed ecosystem functioning in a particular way, with definite ecological (adaptive) life forms as links, we may be able to work out a classification and nomenclature of the types and forms concerned (Krasnov \& Preobrazhensky, 1972; Preobrazhensky, 1975). The development of the theory of life forms ("growth forms") involves the general theory of systems, systemstructure analysis and symmetry theory. These concepts coupled with the Second Principle of symmetry suggested by Pierre Curie bring us to the conclusion that the finite quantity of life forms depends on definite environmental conditions (Preobrazhensky, in press). In this case, the reef appears to be an ecologically and historically stable system, characterized by a standard set of life forms, and by no means limited to a certain period of time.

The problem that a certain set of special lithological and geomorphological elements seems to be a basic requirement for a reef, needs further research. A comparison of different reef types in the western and eastern Pacific (Stoddart, 1969; Külmann, 1970; Dana, 1976), Atlantic and Indian Oceans suggests that reefs do not necessarily have universal morphological or geomorphological features in common. However, in all types of recent and ancient reefs, we find some sets of vicarious animals and plants, amazingly invariable in their form, function and trophic interrelationships.

The study of the nature of a buttress system (Goreau, 1959; Yonge, 1963; Stoddart, 1971; Phipps \& Preobrazhensky, 1977) poses the question whether the buttress system belongs necessarily to the reef and how it originated. Goreau (1959, 1966) believed the buttress system to be a special organic structure occurring on coral reefs with some regularity. Our investigations (Phipps \& Preobrazhensky, 1977) have demonstrated that the buttress system of at least the reefs in New Guinea, Fiji and the Great Barrier Reef of Australia are of karst erosional origin. Stoddart (1969) expressed the same opinion about the nature of a similar system of reefs in the Indian Ocean. Hence, it seems that other morphologic underwater structures (breaker, tract channel, etc.) are not peculiar to the reef, but only characterize a special type of geomorphologic structure of shelf, formed under certain conditions. A reef can also exist without specific facies. The coral constructions in the Southern China Sea possess no typical underwater structures, but the structures of these communities do not differ from those of the reef.

Recognition of the mode of energy exchange may result in establishing trophic analogues of reefs in the abyssal of temperate seas on the basis of settlements of sponges, bryozoans or serpulids. Some hydrobiologists believe that there exists some similarity between the laminarian community and coral reefs. Teichert (1958) reported on coral banks in Norwegian and Islandic fjords at depths over $100 \mathrm{~m}$ and a temperature of $4^{\circ} \mathrm{C}$. These banks are about $70 \mathrm{~m}$ thick in an area covering about 
$3.8 \mathrm{~km}^{2}$. It is likely that energetic analogies to the reef may also be found in fresh water and terrestrial communities.

Quantitative indications of the reef biocoenosis structure (specific number and diversity of organisms) and characteristics of life forms can be considered among the most objective peculiarities, nearly independent of local conditions; these features determine, to a large extent, the nature of the reef complex.

Finally, we may consider a reef as the only successful organization comprising all features mentioned above. The correlative structure of the reef and its separate parts are necessarily associated with the establishment of functional or correlative interconnections between the different links of the coral biocoenoses. If such interconnections between groups of organisms exist, we may claim the existance of specific reef biocenosis in the sense of Moebius. Where such interconnections are lacking, the reef can be interpreted as a structure constituted by an occasional composition of animals and plants. We face a similar dilemma in regard to the mutual correlations between living animals and plants constituting a reef. In this connection, it might be necessary to classify intercorrelations between different life forms determined by their habitus and their ecological specialization (ecologic niche), as well as to develop a general energetic model of the reef.

From the above consideration, it follows that the theory of reef evolution as interpreted by Darwin, Daly, and others (Stoddart, 1969) constitutes a part of a conceptual problem of the reef, seen by Sheer (1974) as a problem of "coral sociology“.

The problems classified by Stoddart as operational include (1) the unification of sampling and analysis of field records; (2) listing of information necessary and sufficient for routine statistical observations on reefs; and (3) the development of field recording methods for underwater examination.

The best current methods for reef exploration presently available involve the application of SCUBA techniques, transects using the quadrat method for quantitative sampling, parallel photo- and cinematographic registration with colour and black-and-white film, and the recording of environmental variables. Field recording methods have been thoroughly discussed (e.g. Forsberg \& Sachet, 1953; Hiatt, 1953; Stoddart, 1972; Sheer, 1974).

Apparently, some problems of physiology, biochemistry and autecology of reef organisms must also be defined as operational. The establishment of vertical and horizontal zonation, as well as biocenotic mapping, should be recognized as significant operational problems.

The solution for these problems calls for considerable interdisciplinary and international effort. It seems desirable to work out a joint programm to be conducted under the auspices of authoritative international institutions.

\section{LITERATURE CITED}

Catala, R., 1950. Contribution a 1' étude écologique des ilots corraliens du Pacifique sud. Premiers elements d' ecologique terrestre at marine des ilots voisins au littoral de la Nouvelle Caledome. Bull. biol. Fr. Belg. 4, 234-310. 
Dana, T. F., 1975. Development of contemporary Eastern Pacific coral reefs. Mar. Biol. 33, 368-374.

Forsberg, R. F. \& Sachet, M. N., 1953. Handbook for atoll research. Atoll Res. Bull. 17, 1-129.

Goreau, Th., 1959. The ecology of Jamaican coral reefs. I. Species composition and zonation. Ecology 40, 67-90.

Hiatt, R. W., 1953 a. Methods of collecting marine invertebrates on coral atolls. Atoll Res. Bull. 17, 78-89.

- 1953 b. Instructions for marine ecological works on coral atolls. Atoll Res. Bull. 17, $100-108$.

Krasnov, E. V. \& Preobrazhensky, B. V., 1972. On the nature and significance of life forms of Tabulate and colonial scleractinian corals. Paleontol. $\mathrm{Zh.}$ 2, 136-140 (Russ.).

Kühlmann, D. H. H., 1970. Die Korallenriffe Kubas. I. Genes und Evolution. Int. Revue ges. Hydrobiol. 55, 726-756.

Mergner, H., 1974. The physiographic zonation and the ecological conditions of some south Indian and Ceylon coral reefs. In: Proceedings of the 2 nd International coral reef symposium. Great. Barrier Reef Comm., Brisbane. 2, 3-30.

Phipps, C. \& Preobrazhensky, B. V., 1977. Structure and general coral distribution on some coral reefs of Fiji (Lau group). In: Proceedings of the 2nd international symposium on corals, Paris, 2, 440-455.

Preobrazhensky, B. V. 1975. On the nomenclature of the life forms of corals. Biol. Morja 1, 23-30 (Russ.).

Scheer, Georg, 1967. Über die Methodik der Untersuchung von Korallenriffen. Z. Morph. Okol. Tiere 60, 105-114.

- 1974. Investigation of coral reefs at Pasdu Atoll in the Maldives with quadrat method according to phytosociology. In: Proceedings of the 2 nd International coral reef symposium. Great Barrier Reef Comm., Brisbane, 1, 655-669.

Stoddart, D. R., 1969. Ecology and morphology of recent coral reefs. Biol. Rev. 44, 433-498.

- 1971. Environment and history in Indian Ocean reef morphology. Symp. zool. Soc. Lond. 28, 3-38.

- 1972. Field methods in the study of coral reefs. In: Proceedings of the symposium on corals and coral reefs. Ed. by G. Mukunda \& C. S. G. Tillon. Mar. biol. Ass. India, Cochin, 1, 71-80.

Teichert, C., 1958. Cold- and deep-water coral banks. Bull. Am. Ass. Petrol. Geol. 42, 1064-1082.

Umgrove, J. N. F., 1940. Madreporaria from the Togian reefs. (Gulf of Tomini, North Celebes). Zoöl. Meded., Leiden 22, 265-310.

Wells, J. W., 1954. Recent corals of the Marshall Islands. Prof. Pap. U. S. geol. Surv. 260, $385-486$.

Yonge, C. M., 1963. The biology of coral reefs. Adv. mar. Biol. 1, 209-260.

Author's address: B. V. Preobrazhensky

Institute of Marine Biology

Vladivostok 690022

USSR 